\title{
Kedudukan Hukum Kreditor Preferen Pajak dan Kreditor Preferen Buruh dalam Proses Kepailitan
}

\author{
Imran Eka Saputra \\ Fakultas Hukum, Universitas Muslim Indonesia \\ ${ }^{\Omega}$ Surel Koresponden: imranekasaputragmail.com
}

\begin{abstract}
:
This study aims to determine the legal position of tax preferred creditors and labor preferred creditors in the bankruptcy process and to determine the factors that influence the occurrence of disputes between labor preference creditors and tax preferred creditors in the bankruptcy process. The research method used is a method with the type of normative research using 2 (three) types of approaches, namely the statutory approach (statute approach) and the conceptual approach (conceptual approach). The results of this study are based on a conceptual approach and a statutory approach, the authors find that the legal position of tax preferred creditors and workers' preferences is the same. law, the factor of justice, the factor of increasing public welfare (public interest), the factor of labor rights and human rights. In order to provide certainty about the legal position of tax preferred creditors and labor preferred creditors, it is deemed necessary to improve the bankruptcy law, so that there are no problems between tax preferred creditors and labor preferred creditors in the bankruptcy process. Factors that influence the occurrence of disputes between labor preference creditors and tax preferred creditors in the bankruptcy process can be input for members of the House of Representatives and the Government to improve the bankruptcy law
\end{abstract}

Keywords: Creditors; Preference; Laborer; Tax; bankruptcy;

\begin{abstract}
Abstrak:
Penelitian ini bertujuan untuk mengetahui kedudukan hukum kreditor preferen pajak dan kreditor preferen buruh dalam proses kepailitan dan mengetahui faktor-faktor yang mempengaruhi terjadinya sengketa antara kreditor Preferen buruh dan kreditor preferen pajak dalam proses kepailitan. Metode penelitian yang digunakan adalah metode dengan jenis penelitian normative menggunakan 2 (tiga) tipe pendekatan yakni pendekatan perundang-undangan (statute approach), dan pendekatan konseptual (conceptual approach). Hasil dari penelitian ini adalah berdasarkan pendekatan konseptual dan pendekatan perundang-undangan penulis menemukan bahwa kedudukan hukum kreditor preferen pajak dan preferen buruh mempunyai kedudukan yang sama, Adapun yang menjadi faktor-faktor yang mempengaruhi terjadinya sengketa antara kreditor Preferen buruh dan kreditor preferen pajak adalah faktor kepastian hukum, faktor keadilan, faktor meninggikan kesejahteraan umum (kepentingan umum), faktor hak-hak buruh dan hak asasi manusia. Dalam rangka memberikan kepastian kedudukan hukum terhadap kreditor preferen pajak dan kreditor preferen buruh maka dirasa perlu untuk menyempurnakan undang undang kepailitan,agar tidak terjadi permasalahan antara kreditor preferen pajak dan kreditor preferen buruh dalam prose kepailitan. Faktor-faktor yang mempengaruhi terjadinya sengketa antara kreditor Preferen buruh dan kreditor preferen pajak dalam proses kepailitan ini bisa menjadi masukan bagi para anggota Dewan Perwakilan Rakyat dan Pemerintah untuk menyempurnakan undang undang kepailitan
\end{abstract}


Kata Kunci: Kreditor; Preferen; Buruh; Pajak; Kepailitan;

Submit : 10-08-2020

Accept : $19-10-2020$

Doi: http://doi.org/10.56087/aijih.v23i2.44

\section{PENDAHULUAN}

Kepailitan dalam Black's Laws Dictionary adalah The State or condition of a person (individual, parthnership, or corporation, municipality) who is unable to pay its debt as they are, or become due". The term includes a person agains whom an involuntary petition has been filed, or who has filed a voluntary petition, or who has been adjudged a bankrupt."1 Dari pengertian tersebut, dapat kemukakan bahwa pailit dihubungkan dengan "ketidakmampuan untuk membayar" dari seorang (debitor) atas utangutangnya yang telah jatuh tempo. Ketidakmampuan tersebut harus disertai dengan suatu tindakan nyata untuk mengajukan, baik yang dilakukan secara sukarela oleh debitor sendiri, maupun atas permintaan pihak ketiga (diluar debitor), suatu permohonan pernyataan pailit ke pengadilan. ${ }^{2}$

Debitor adalah pihak yang memiliki kewajiban kepada Kreditor, yaitu kewajiban untuk membayar utangnya kepada Kreditor. Sehingga para Kreditor dalam kepailitan memiliki hak-hak yang harus dilindungi. ${ }^{3}$ Maka dari itu, kemudian muncullah ketentuan kepailitan yang bertujuan untuk melakukan pembagian kekayaan milik debitor kepada para kreditornya dengan melakukan sitaan bersama dan kekayaan debitor dapat dibagikan kepada kreditor sesuai dengan haknya. Berkaitan dengan ini berlaku ketentuan Pasal 1131 dan Pasal 1132 Kitab UndangUndang Hukum Perdata yang mengatur dan memberikan kedudukan para kreditor sebagai kreditor konkuren sehingga boedel pailit akan dibagikan kepada para kreditor secara seimbang (ponds gewijs/paritas creditorium), kecuali apabila diberikan perkecualian oleh undang-undang, yaitu sebagaimana tertera dalam Pasal 1131 dan Pasal 1132 Kitab Undang-Undang Hukum Perdata. ${ }^{4}$

1 Asikin, Z. (2001). Hukum Kepailitan dan Penundaan Pembayaran di Indonesia. RajaGrafindo Persada. Hlm. 57.

2 Yani, A., \& Widjaja, G. (2002). Seri Hukum Bisnis Kepailitan. Jakarta: Raja Grafindo Persada. hlm. 23.

3 Rahmani, I. (2018). Perlindungan Hukum Kepada Pembeli Dalam Kepailitan Pengembang (Developer) Rumah Susun. Jurnal Hukum Bisnis Bonum Commune, 1(1), hlm. 75.

${ }^{4}$ Hartono, S. R. (2007). Hukum Ekonomi Indonesia. Bayumedia Pub. hlm. 80. 
Kreditor dibagi menjadi tiga golongan yaitu: Kreditor Separatis; Kreditor Preferen; dan Kreditor Konkuren. ${ }^{5}$ (Lihat juga penjelasan Pasal 2 ayat (1) UU No. 37 Tahun 2004 Tentang Kepailitan dan Penundaan Kewajiban Utang (selanjutnya disebut UU 37/2004): Yang dimaksud dengan "Kreditor" dalam ayat ini adalah baik kreditor konkuren, kreditor separatis maupun kreditor preferen. Khusus mengenai kreditor separatis dan kreditor preferen, mereka dapat mengajukan permohonan pernyataan pailit tanpa kehilangan hak agunan atas kebendaan yang mereka miliki terhadap harta Debitor dan haknya untuk didahulukan). Pembedaan menurut UU No. 37/2004 tersebut, berhubungan dengan posisi kreditor bersangkutan dalam proses pembagian harta pailit. Inilah pertimbangan pembentukan UU No.37/2004, yakni sebagai salah satu sarana hukum untuk menyesaikan utang piutang secara cepat, adil, terbuka, efektif, sehingga menjadi kewajiban bagi semua pihak yang terlibat dalam proses kepailitan termasuk Majelis Hakim Niaga yang mengadili dan memutuskan perkara kepailitan. ${ }^{6}$

Kreditor preferen adalah kreditor yang memiliki hak istimewa atau hak prioritas. Hak istimewa mengandung arti hak yang oleh undang-undang diberikan kepada seorang berpiutang sehingga tingkatnya lebih tinggi dari pada orang berpiutang lainnya, merujuk pada KUH Perdata, terdapat dua jenis hak istimewa, yaitu hak istimewa khusus (Pasal 1139 KUHPerdata) yaitu hak istimewa yang menyangkut benda-benda tertentu dan hak istimewa umum (Pasal 1149 KUH Perdata) yaitu menyangkut seluruh benda. Sesuai dengan ketentuan KUH Perdata pula, hak istimewa khusus didahulukan atas hak istimewa umum (Pasal 1138 KUH Perdata).

Kepailitan dianggap lebih efisien dan memberikan tekanan lebih terhadap Debitor mengingat akibat hukum yang ditimbulkan juga lebih beresiko sehingga mereka takut dan berusaha semaksimal mungkin melakukan upaya seperti perdamaian atau mengajukan PKPU agar perusahaannya tidak jadi pailit. ${ }^{7}$ Dalam hal kepailitan terdapat dua kreditor preferen yang bertentangan terkait dengan yang mana akan menjadi prioritas atau didahulukan dalam pemberasan harta pailit yaitu upah buruh dan utang pajak

\footnotetext{
${ }^{5}$ Makmur, S. (2018). Kepastian Hukum Kepailitan Bagi Kreditor dan Debitur Pada Pengadilan Niaga Indonesia. Mizan: Journal of Islamic Law, 4(2). hlm. 338.

6 Simanjuntak, H. A. (2019). Penyelesaian Utang Debitur Terhadap Kreditor Melalui Kepailitan. Jurnal Justiqa, 1(1). hlm. 10.

${ }^{7}$ Hamdi, H. (2020). Perlindungan Hukum Bagi Kreditor Terhadap Pelunasan Piutang Dari Harta Pailit. Jurnal Ilmiah Mahasiswa Fakultas Hukum, 1(1). hlm. 1416.
} 
Tagihan pembayaran upah buruh dikategorikan sebagai hak istimewa umum (Pasal 1149 KUH Perdata) Ketentuan tersebut juga diatur di dalam pasal 95 ayat 4 UU No. 13/2003 tentang Ketenagakerjaan yang mengatur:

Dalam hal perusahaan dinyatakan pailit atau dilikuidasi berdasarkan peraturan perundang-undangan yang berlaku, maka upah dan hak-hak lainnya dari pekerja/buruh merupakan utang yang didahulukan pembayarannya.

Berkaitan dengan utang pajak mempunyai kedudukan yang penting sehingga kedudukannya tidak dapat dihapuskan, termasuk dalam keadaan pailit. Hal ini telah ditegaskan dalam UU 37/2004 yang memberikan kedudukan utama dari pajak sebagai kewajiban yang harus didahulukan. KUH Perdata telah menempatkan utang pajak untuk didahulukan dari pada kreditor lainnya sebagaimana diatur dalam Pasal 1137. Maka menurut pasal ini kedudukan utang pajak sebagai pemegang hak istimewa dengan hak mendahulu yang merujuk pada pengaturan dalam undangundang khusus, yaitu Undang-Undang Nomor 16 Tahun 2009 tentang Penetapan Peraturan Pemerintah Pengganti Undang-Undang Nomor 5 Tahun 2008 tentang Perubahan Keempat Atas Undang-Undang Nomor 6 Tahun 1983 tentang Ketentuan Umum Dan Tata Cara Perpajakan Menjadi Undang-Undang (selanjutnya disebut KUP). Dalam tulisan ini, Penulis akan membahas bagaimanakah kedudukan hukum posisi masing-masing kreditor preferen dalam proses kepailitan, dan yang manakah yang terlebih dahulu pembayarannya di dahului apakah upah buruh (Kreditor Preferen buruh) ataukah Pembayaran hutang pajak (kreditor preferen pajak) yang terlebih dahulu.

\section{METODE}

Tipe penelitian ini merupakan penelitian hukum normatif dengan melalui dua tataran yakni pada tataran dogmatik hukum dan tataran teori hukum (Agak berbeda dengan model penulisan di Amerika Serikat yang intoductionnya diawali dengan theses sentence yang berupa pernyataan akan temuan atau argumentasi yang didapatkan dalam penelitian itu, hal mana metodologi tidak harus dikemukakan. ${ }^{8}$ Sebagai penelitian hukum normatif, tipe pendekatan yang digunakan dalam

${ }^{8}$ Mahmud Marzuki, P. (2005). Penelitian hukum. Jakarta: Kencana Prenada Media, 55. hlm. 183. 
penelitian ini adalah pendekatan perundang-undangan (statute approach), dan pendekatan konseptual (conceptual approach).

Adapun bahan hukum yang digunakan dalam penelitian ini adalah sebagai berikut: Penelitian ini menggunakan penalaran deduktif guna mendapatkan dan menemukan kebenaran objektif, yang mendasarkan diri pada aspek normatif, kasus, dan konseptual. Penalaran deduktif digunakan untuk mengkaji objek penelitian tersebut dengan menjadikan aspek normatif dan aspek konseptual dari Kedudukan hukum kreditor preferen pajak dan kedudukan kreditor preferen buruh dalam prose kepailitan pada umumnya sebagai premis mayor yang akan menghasilkan kesimpulan dalam rangka menjawab rumusan masalah di atas sebagai premis minor.

\section{HASIL DAN PEMBAHASAN}

\section{Kedudukan Kreditor Preferen Buruh}

Di dalam sistem pengupahan, dikenal adanya beberapa prinsip sebagai berikut: ${ }^{9}$

a) Hak menerima upah timbul pada saat adanya hubungan kerja dan berakhir pada saat hubungan kerja putus;

b) Pengusaha tidak boleh mengadakan diskriminasi upah bagi pekerja/buruh laki-laki dan wanita untuk jenis pekerjaan yang sama;

c) Upah tidak dibayar apabila pekerja/buruh tidak melakukan pekerjaan (" $n o$ work no pay");

d) Komponen upah terdiri dari upah pokok dan tunjangan tetap;

e) Tuntutan pembayaran upah pekerja/buruh dan segala pembayaran yang timbul dari hubungan kerja menjadi kadaluarsa setelah melampaui jangka waktu 2 (dua) tahun sejak timbulnya hak.

Upah pekerja atau buruh termasuk dalam hak istimewa atas semua benda bergerak dan tak bergerak pada umumnya, sehingga kedudukannya adalah setelah hak istimewa yang mengenai benda-benda tertentu. Dengan dikelompokkannya upah pekerja atau buruh dalam hak istimewa atas benda pada umumnya (general statutory priority) sebagaimana diatur dalam Pasal

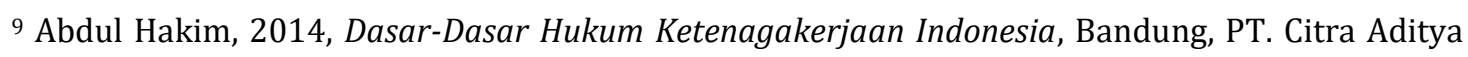
Bakti. 
1149 KUH Perdata, maka KUH Perdata telah menempatkan kedudukan utang upah pekerja pada urutan ketiga setelah kreditor pemegang hak jaminan kebendaan, dan kreditor hak istimewa atas barang tertentu.

Demikian pentingnya upah buruh bagi kehidupan buruh, yang mana hak asasinya telah dituangkan secara jelas dalam konstitusi negara tersebut. Seperti halnya di Amerika Serikat, walaupun termasuk Negara kapitalis, namun kedudukan upah buruh dianggap penting dan diprioritaskan dari utang pajak, hal tersebut dapat dilihat dari kasus 11.U.S.C. (Supp. V,1958)104 (a) yang telah menempatkan upah buruh dalam prioritas kedua dan utang pajak dalam prioritas keempat.

"The debts to have priority... and the order of payment, shall be... (2) wages habe been earned within three months before the date of the commencement of the proceeding, due to workmen... (4) taxes legally due and owing by bankrupt to the United States.."

Tagihan pembayaran upah buruh dikategorikan sebagai hak istimewa umum (Pasal 1149 KUH Perdata) Ketentuan tersebut juga diatur di dalam pasal 95 ayat 4 UU No. 13/2003 tentang Ketenagakerjaan.

UU 37/2004 mengatur bahwa sejak tanggal putusan pernyataan pailit diucapkan, upah yang terutang sebelum, maupun sesudah putusan pernyataan pailit diucapkan merupakan utang harta pailit (pasal 39 ayat 2). Dengan sendirinya, kurator wajib untuk mencatat, sekaligus mencantumkan sifat (istimewa) pembayaran upah yang merupakan utang harta pailit dalam daftar utang piutang harta pailit (Pasal 102 jo. 100 UU No. 37/2004). Daftar tersebut harus diumumkan pada khalayak umum (Pasal 103 UU No. 37/2004) sebelum akhirnya dicocokkan dengan tagihan yang diajukan oleh kreditor sendiri (Pasal 116 UU No. 37 /2004).

\section{Kedudukan Kreditor Preferen Pajak}

Sinninghe Damste dalam Inleiding tot het Nederlands Belastingsrecht menyatakan bahwa ia tidak dapat mengatakan dengan tegas apakah tentang pemberian hak mendahului kepada masing-masing pajak itu ada patokannya tertentu atau tidak. Namun pemberian hak mendahulu bukanlah suatu hal yang 
kebetulan saja atau digantungkan kepada kesempatan yang dianggap baik belaka.

Kekuasaan fiskus untuk menuntut pelunasan utang pajak dengan langsung sebenarnya dipermudah dengan adanya hak mendahulu yang diberikan UndangUndang. Adriani mengatakan hak mendahului merupakan hak fiskus atas kekuasaan negara. Suatu utang atau tagihan pajak harus dilunasi oleh wajib pajak atau Penanggung Pajak. Dengan adanya tagihan pajak, negara mempunyai hak mendahulu untuk tagihan pajak tersebut atas barang-barang milik Penanggung Pajak, sebagaimana bunyi Pasal 21 ayat (1) UU KUP.

Adapun maksud dari adanya hak mendahulu negara ini dijelaskan lebih lanjut dalam Penjelasan Pasal 21 ayat (1) UU KUP, yaitu untuk menetapkan kedudukan negara sebagai Kreditor preferen yang mempunyai hak mendahulu atas barang barang milik Penanggung Pajak yang akan dilelang di muka umum. Utang pajak merupakan aturan khusus, oleh karena itu negara melalui Direktorat Jenderal Pajak mempunyai "hak mendahulu" untuk melaksanakan sita atas barang-barang wajib pajak yang manjadikan barang-barang miliknya atau asetnya sebagai jaminan atas utang-utangnya, seperti yang diatur dalam Pasal 21 UU KUP tersebut.

Pelaksanaan hak mendahulu negara atas utang pajak tersebut adalah dengan dilakukan pembayaran atas utang pajak terlebih daulu, pembayaran kepada Kreditor lain diselesaikan setelah utang pajak dilunasi. Ketentuan tentang hak mendahulu meliputi pokok pajak, sanksi administrasi berupa bunga, denda, kenaikan, dan biaya penagihan pajak. Selain itu, di sisi lain terdapat pula pengecualian mendahulu untuk utang pajak ini; pertama, biayan perkara yang hanya disebabkan oleh suatu penghukuman untuk melelang suatu barang bergerak dan/atau barang tidak bergerak; kedua, biaya yang telah dikeluarkan untuk menyelamatkan barang dimaksud; dan/ata ketiga, biaya perkara, yang hanya disebabkan oleh pelelangan dan penyelesaian suatu warisan.

Dilihat dari definisi utang dalam UU 37/2004 secara luas, utang merupakan kewajiban yang dapat timbul dari perjanjian atau dari perikatan karena undangundang. Sementara pemahaman pajak dari persepektif hukum menurut Soemitro 
merupakan suatu perikatan yang timbul karena adanya undang-undang yang menyebabkan timbulnya kewajban warga negara untuk menyetorkan sejumlah penghasilan tertentu kepada negara, dimana Negara mempunyai kekuatan untuk memaksa dan uang pajak tersebut harus dipergunakan untuk penyelenggaraan pemerintah. ${ }^{10}$

\section{Hak Mendahului Kreditor Preferen Buruh atas Kreditor Preferen Pajak}

Berdasarkan Pasal 21 UU KUP, maka posisi kreditor preferen pajak didahulukan terhadap semua kreditor lain. Namun, setelah keluarnya Putusan MK No 67/PUUXI/2013 tentang pengujian UU 13/2003 tentang Ketenagakerjaan, prioritas pelunasan utang pailit mengalami perubahan. Inti permohonan pemohon dalam hal ini adalah mengenai frasa "didahulukan pembayarannya" yang terdapat dalam Pasal 94 ayat (4) yang berbunyi dalam hal perusahaan dinyatakan pailit atau dilikuidasai berdasarkan peraturan perundang-undangan yang berlaku, maka upah dan hak-hak lainnya dari pekerja/ buruh merupakan utang yang didahulukan pembayarannya. Menurut pemohon, frasa didahulukan pembayarannya tidak memberikan kepastian hukum mengenai pelunasan utang kepada para kreditor.

Pada dasarnya KUH Perdata dan UU 37/2004 telah menetapkan urutan prioritas pelunasan utang kreditor. Namun oleh karena kedua atauran tersebut adalah lex generalis, maka ketentuannya dapat dikesampingkan apabila diatur berbeda menurut peraturan yang lebih khusus. Terdapat setidaknya tiga undang-undang sebagai lex specialis atas KUHPerdata dan UU 37/2004 terkait hal ini; UU 2/1992 tentang Perasuransian ${ }^{11}$, UU Ketenagakerjaan, dan UU KUP. Menurut pemohon, dalam praktiknya hampir selalu terdapat tarik menarik kepentingan antara pemegang polis asuransi, buruh, dan lembaga pajak untuk didahulukan haknya.

Dalam putusan a quo, mahkamah menetapkan bahwa Pasal 95 ayat (4) UU Ketenagakerjaan bertentangan dengan UUD 1945 sepanjang tidak dimaknai "pembayaran upah pekerja/ buruh yang terhutang didahulukan atas semua jenis kreditur termasuk atas tagihan kreditur separatis, tagihan hak negara, kantor lelang,

10 Rochmat Soemitro, 1992, Pengantar Singkat Hukum Pajak, Bandung, Eresco, hlm. 11.

11 Paska Putusan MK 67/PUU-XI/2013 terbit UU Asuransi yang baru yakni UU 40/2014 sebagai pengganti UU 2/1992. 
dan badan umum yang dibentuk pemerintah, sedangkan pembayaran hak-hak pekerja/buruh lainnya didahulukan atas semua tagihan termasuk tagihan hak negara, kantor lelang, dan badan umum yang dibentuk pemerintah, kecuali tagihan dari kreditu separatis.

Dengan demikian, mahkamah berpendapat bahwa antara "upah" dan "hak-hak buruh/pekerja lainnya" merupakan dua hal yang berbeda prioritas pelunasannya. Upah dipandang sebagai hak vital buruh yang pembayarannya didahulukan atas semua jenis kreditur termasuk atas tagihan kreditur separatis, tagihan hak negara, kantor lelang, dan badan umum yang dibentuk pemerintah. Sedangkan untuk hakhak pekerja/buruh lainnya dibayarkan berikutnya setelah kreditur separatis.

Dengan demikian, berdasarkan putusan a quo, prioritas pelunasan hutang dalam proses kepailitan adalah sebagai berikut:

1. Upah pekerja/ buruh;

2. Kreditor separatis;

3. Hak-hak pekerja/buruh lainnya;

4. Tagihan hak negara, kantor lelang dan badan umum yang dibentuk pemerintah;

5. Kreditor konkruen.

Untuk menguatkan argumen di atas, penulis menyajikan satu contoh kasus yang terkait.

\section{Studi Putusan No. 24/Plw.Pailit/2014/PN.Niaga.Sby}

Kasus ini melibatkan Kepala Kantor Pajak Pratama Mojokerto sebagai pelawan dan Tim Kurator PT. Integra Lestari sebagai terlawan. Bahwa besarnya pembagian harta pailit yang diterima pelawan adalah senilai Rp.10.318.032.679,00 (sepuluh milyar tiga ratus delapan belas juta tiga puluh dua ribu enam ratus tujuh puluh sembilan rupiah), sedangkan total piutang pajak yang diakui oleh kurator adalah senilai Rp.15.001.560.248,00 (lima belas milyar satu juta lima ratus enam puluh ribu dua ratus empat puluh delapan rupiah). Sehingga dengan ini pelawan menuntut agar terlawan mengutamakan pelunasan piutang pajak sebesar 15 miliar tersebut di atas kreditor lainnya. 
Perlawanannya pelawan mengklaim berhak didahulukan pelunasan piutangnya di atas semua kreditor lain dengan berdasar hukum kepada Pasal 1137 KUHPerdata, Pasal 21 UU KUP, Pasal 19 ayat (5) dan ayat (6) UU 19/1997 tentang Penagihan Pajak dengan Surat Paksa, dan Putusan MA No. 70/PK/Pdt.Sus.2009. Keempat dasar hukum yang digunakan pelawan ini pada intinya adalah benar mendahulukan kreditor preferen pajak di atas semua kreditor lain bahkan terhadap kreditor separatis.

Piutang Pajak merupakan hak Kas Negara yang pelunasannya harus didahulukan daripada pembayaran piutang kepada kreditur-kreditur lainnya dan Kurator bertanggung jawab dalam melaksanakan pelunasan utang pajak tersebut (Pasal 32 ayat (1) huruf b dan ayat (2) UU KUP Jo Pasal 1 angka 3 UU PPSP). Dengan kata lain Kurator seharusnya mendahulukan/mengutamakan pelunasan Utang Pajak sebesar Rp.15.001.560.248,00 (lima belas milyar satu juta lima ratus enam puluh ribu dua ratus empat puluh delapan rupiah) dari boedel pailit PT. Integra Lestari (dalam Pailit)

Adapun pada kenyataanya, dana dari hasil penjualan aset PT. Integra Lestari (dalam pailit) bahkan tidak mencukupi untuk sekadar melunasi utang perusahaan kepada kreditor separatis. Maka jika mengacu pada urutan pelunasan piutang sebagaimana diputuskan MK, kreditor preferen pajak seharusnya tidak akan mendapatkan bagian apapun karena kreditor separatis juga belum mendapat haknya secara penuh. Namun karena kreditor separatis tidak mengajukan keberatan, maka dianggap setuju dengan Daftar Pembagian Harta yang ditetapkan kurator. Pertimbangannya, majelis hakim kemudian berpegang teguh pada Putusan MK No. 67/PUU-XI/2013. Dalam putusan $a$ quo, mahkamah menempatkan pelunasan piutang pajak pada urutan ketiga setelah kreditor preferen buruh dan kreditor separatis.

Memperhatikan Pasal 192 Undang-Undang No. 37 tahun 2004 tentang Kepailitan dan Penundaan Kewajiban Pembayaran Utang, Pasal 1137 KUHPerdata, Pasal 21 ayat (1), ayat (2), ayat (3) dan ayat (3A) Undang-Undang Nomor 6 Tahun 1983 tentang Ketentuan Umum dan Tata Cara Perpajakan sebagaimana telah diubah beberapa kale terakhir dengan Undang-Undang Nomor 16 Tahun 2009 (UU KUP), Pasal 19 ayat (5) dan ayat (6) Undang-Undang Nomor 19 Tahun 1997 tentang Penagihan Pajak Dengan Surat Paksa sebagaimana telah diubah terakhir dengan Undang-Undang Nomor 19 Tahun 2000 (UU PSP), hakim menolak perlawanan/keberatan yang 
diajukan oleh PELAWAN/Kantor Pelayanan Pajak Pratama Mojokerto terhadap Daftar Pembagian Tahap II Harta Pailit PT. Integra Lestari (Dalam Pailit) Tanggal 28 Oktober 2014 untuk seluruhnya.

Olehnya, Majelis Hakim Pengadilan Niaga pada Pengadilan Negeri Surabaya mengganggap pembagian harta pailit yang ditetapkan oleh kurator telah sesuai dengan peraturan perundangan yang berlaku. Dalam amar majelis hakim memutuskan menolak perlawanan/keberatan yang diajukan pelawan untuk seluruhnya. Berdasarkan putusan ini, semakin menguatkan bahwa posisi kreditor preferen buruh berada di atas kreditor preferen pajak.

\section{KESIMPULAN}

Kedudukan hukum kreditor preferen dalam hal ini upah buruh dan pajak yang berdasarkan pada Pasal 21 UU KUP, kreditor preferen pajak didahulukan, namun, setelah diterbitkannya Putusan MK No 67/PUU-XI/2013 tentang pengujian UU 13/2003 tentang Ketenagakerjaan, kreditor preferen upah buruh dipandang sebagai hak vital yang pembayarannya didahulukan atas semua jenis kreditur. Pada Putusan No. 24/Plw.Pailit/2014/PN.Niaga.Sby, majelis hakim kemudian berpegang teguh pada Putusan MK No. 67/PUU-XI/2013. Dalam putusan a quo, mahkamah menempatkan pelunasan piutang pajak pada urutan ketiga setelah kreditor preferen buruh dan kreditor separatis. Berdasarkan putusan tersebut, menguatkan bahwa posisi kreditor preferen buruh berada di atas kreditor preferen pajak. Penulis berharap kedepannya pembentuk regulasi mengimplementasikan Putusan MK No 67/PUU-XI/2013 dalam sebuah peraturan perundang-undangan.

\section{REFERENSI}

Asikin, Z. (2001). Hukum Kepailitan dan Penundaan Pembayaran di Indonesia. RajaGrafindo Persada.

Dewi, K. S., \& Markeling, I. K. (2018). Kedudukan Utang Upah Pekerja Dalam Kepailitan. Jurnal Fakultas Hukum Udayana, 6(02). 
Hamdi, H. (2020). Perlindungan Hukum Bagi Kreditor Terhadap Pelunasan Piutang Dari Harta Pailit. Jurnal Ilmiah Mahasiswa Fakultas Hukum, 1(1).

Hartono, S. R. (2007). Hukum Ekonomi Indonesia. Bayumedia Pub.

Hatta, H. (2018). Kontradiktif Penerapan Hukum Pajak Berganda Di Indonesia. Al-Ishlah: Jurnal Ilmiah Hukum, 20(1), 50-58.

Mahmud Marzuki, P. (2005). Penelitian hukum. Jakarta: Kencana Prenada Media, 55.

Makmur, S. (2018). Kepastian Hukum Kepailitan Bagi Kreditor dan Debitor Pada Pengadilan Niaga Indonesia. Mizan: Journal of Islamic Law, 4(2).

Rahmani, I. (2018). Perlindungan Hukum Kepada Pembeli Dalam Kepailitan Pengembang (Developer) Rumah Susun. Jurnal Hukum Bisnis Bonum Commune, 1(1).

Simanjuntak, H. A. (2019). Penyelesaian Utang Debitor Terhadap Kreditor Melalui Kepailitan. Jurnal Justiqa, 1(1).

Sutan Remy Sjahdeini, S. H. (2016). Hukum Kepailitan (Memahami undang-undang No. 37 Tahun 2004 tentang Kepailitan). Kencana.

Yani, A., \& Widjaja, G. (2002). Seri Hukum Bisnis Kepailitan. Jakarta: Raja Grafindo Persada. 